закладів, нормативно-правове регулювання навчально-виховного процесу та педагогічних відносин, засади правового регулювання коміторних правовідносин, суміжних із педагогічними правовідносинами, має сформовану правосвідомість, уміє всебічно оцінювати правову ситуацію та знаходити оптимальне рішення, уміє використовувати норми права в складних ситуаціях.

5. Найвищий рівень характеризується: наявністю системних правових знань, умінням саморегуляції, високою соціальною рефлексією, самовдосконаленням особистої правової культури, інженер-педагог має яскраво виражену правову свідомість, прагнення до правового самоконтролю, прагнення творчого використання правових норм у професійній діяльності, активно опановує правовий досвід.

Отже, аналіз психолого-педагогічної літератури, практики професійної підготовки інженерів-педагогів э можливість виявити такі критерії оцінки рівня сформованості їх правової культури: мотиваційно-ціннісний, когнітивно-інформаційний, діяльнісно-поведінковий та оцінно-рефлексивний.

1. Белкин А. С. Диссертационный совет по педагогике (опыт, проблемы, перспективы) // А. С. Белкин, Е. В. Ткачев. - Екатеринбург : УрГПУ, 2005 - 248 с. 2. Сливка С. С. Юридична деонтологія: [підручник] / С. С. Сливка. - [3-те вид., перероб. та доп.]. - К. : Юрінком Інтер, 2002. 736 с. 3. Твердохліб Л. В. Формування правової культури старшокласників у навчальних закладах нового типу : автореф. дис. на здобуття наук. ступеня канд. пед. наук : спец. 13.00.01 «Теорія та історія педагогіки» / Л. В. Твердохліб. - Луганськ, 1999. - 22 с.

УДК 510.8:005.35:005.932

Владислав Фадєєв

\title{
ТЕОРЕТИЧНІ АСПЕКТИ МОДЕЛЮВАННЯ УПРАВЛІННЯ ОСВІТНІМИ РЕСУРСАМИ ВИЩОЇ ОСВІТИ В УКРАЇНI
}

Фадєєв В. І. Теоретичні аспекти моделювання управління освітніми ресурсами вищої освіти в Україні.

Стаття присвячена аналізу теоретичних особливостей моделювання управління освітніми ресурсами вищих навчальних закладів. Досліджено особливості застосування системного підходу до моделювання управління освітніми ресурсами вищої освіти України.

Ключові слова: система, моделювання, управління, освітні ресурси, вищі навчальні заклади.

Фадеев В.И. Теоретические аспекты моделирования управления образовательными ресурсами высшего образования в Украине.

Статья посвящена анализу теоретических особенностей моделирования управления образовательными ресурсами высших учебных заведений. Исследованы особенности применения системного подхода к моделированию управления образовательными ресурсами высшего образования Украины.

Ключевые слова: система, моделирование, управление, образовательные ресурсы, высшие учебные заведения.

Fadeev V. I. The theoretical aspects of modeling the management of educational resources of higher education in Ukraine

This article analyzes the characteristics of theoretical modeling of management of educational resources of higher education. The features of a systems approach to modeling the management of educational resources of higher education in Ukraine are researched.

Key words: system, modeling, management, educational resources, higher education.

Розвиток і функціонування освіти як відкритої, динамічної соціально-педагогічної системи потребує створення ефективної системи управління, яка має досить складний і розгалужений характер. Це вимагає розгляду певних методологічних засад створення моделі системи управління системою вищої освіти, у тому числі освітніми ресурсами вищих навчальних закладів України. Під час процесу організації цього процесу особливої уваги набуває розгляд 
питань застосування системного підходу до управління освітніми ресурсами вищої школи України.

Методологічні засади розвитку науки, і педагогічної науки зокрема, відображено в значній кількості робіт. Це наукові праці В. Буряка, О. Глузмана, С. Гончаренка, М. Данилова, В. Кременя, В. Нікіфорова, Ю. Сурміна, М. Фіцули, Е. Юдіна та ін. Особливості системного підходу грунтовно висвітлені як у роботах зарубіжних, так і вітчизняних авторів: М. Альберт, В. Беспалько, Ю. Конаржевський, Г. Кунд, В. Лазарев, М. Мескон, С. О’Доннел, С. Оптнер, У. Оучи, В. Пікельна, Стефан П. Робіне, Ю. Сурмін, Ф. Хедоурі та ін.

Недослідженими залишаються особливості моделювання управління освітніми ресурсами вищих навчальних закладів.

Мета статmі - проаналізувати теоретичні аспекти моделювання процесу управління освітніми ресурсами вищих навчальних закладів.

Одним із ефективних методів пізнання, трансформації і модернізації традиційної освітньої парадигми вважаємо моделювання. Моделювання - дослідження об'єктів пізнання на їх моделях, а також побудова й вивчення моделей реальних явищ. Науковою базою моделювання як одного з головних методів пізнання і дослідження, який може бути спрямований на різні об'єкти і процеси, є теорія подібності, де головним є поняття аналогії, що означає схожість об'єктів за деякими ознаками. При цьому аналогія між об'єктами може бути встановлена за якісними й кількісними ознаками. 3-поміж багатьох відомих видів моделювання основними $є$ математичне, імітаційне й статистичне, що можуть продуктивно й спільно застосовуватись у процесі дослідження різних систем, зокрема, системи освіти. Модель - уявлена або матеріалізована система, що відображає й відтворює цей об'єкт дослідження (природний чи соціальний), яка здатна замінити цей об'єкт так, що її вивчення надає нові відомості про нього [10]. Метою побудови моделей є створення штучних об'єктів, за допомогою яких з суттєвих для подальшого використання моделі позицій подаються (відображаються) реальні явища i/або системи. На думку М. Амосова, «...будь-яке пізнання є моделюванням» [10, с. 58].

Загальнонаукові поняття «модель» і «моделювання» $є$ важливими і водночас складними інструментами для педагогіки. В. Михєєв уважає, що моделювання в педагогіці має кілька напрямів для використання: - гносеологічний (модель $є$ проміжним об'єктом у процесі аналізу навчально-виховного процесу; - загальнометодологічний (модель $\epsilon$ підставою для оцінювання зв'язків і відношення між різними складниками навчально-виховного процесу й особливостями їх стану, залежно від рівня їх вивчення і глибини їх опису; - психологічний (дозволяється описування навчально-педагогічної діяльності з різних сторін, після чого можливе виявлення психолого-педагогічних закономірностей $[9$, с. 8]. Як зазначає Є. Лодатко, у будь-якій системі, не може існувати така модель, яка б показували найбільш повний й остаточний перелік особливостей фунціонування такої системи. Виходячи з цього положення, можна зробити такий висновок, що спроба побудови ідеальної «всеохоплюючої» моделі будь-якої системи не наблизить дослідників до максимальної інформації про цю систему й особливостей іiі функціонування, а тільки призведе до максимального ускладнення дій, які можуть бути безрезультатними. Головним $є$ добір якісних ознак, які дозволять розробити модель, визначити рівень абстрагування під час їх опису та одночасному аналізу їх характеристик та їх зв'язків 3 іншими соціокультурними явищами. Добір цих ознак моделювання свідчить про інформативність окресленої моделі, комфортність і легкість іiі викоритання, відповідність цієї моделі іншим об'єктам цієї системи, прозорість механізму управління навчально-виховним процесом за допомогою впливу на його окремі компоненти [8]. Як свідчать результати термінологічного аналізу Н. Глузман [5], поняття «модель» розуміють: у широкому значенні: як систему, що мисленнєво уявляється або матеріально реалізується і під час відображення або відтворення об'єкта дослідження може змінювати його так, що іï вивчення надає нову інформацію про аналізований об'єкт; у вузькому значенні: зображення певного явища за допомогою іншого, більш вивченого, яке легше зрозуміти; як спрощені теорії, що дозволяють вивчати взаємозв'язки між різними індикаторами в суспільстві; як схему, графік будь-якого об'єкта, процесу або явища, що використовується як його спрощена заміна. Визначальним принципом моделювання $\epsilon$ збереження структурно-функціональної відповідності між моделлю і модельованим об'єктом. До основних методологічних принципів педагогічного моделювання науковці відносять такі: принцип цілеспрямованості та підпорядкованості меті; ієрархічної взаємозумовленості й 
узгодженості; реальності виконання; конкретності; передбачуваності; зворотного зв'язку стосовно стану досягнутого результату; функціонально-логічної структуризації системності; суперечливості (єдність інтуїтивно-змістового та формального методів вивчення об'єкта); наочності; визначеності; об'єктивності; концептуальної єдності аксіоматичного і змістовоекзистенціального аспектів; інформаційної достатності. Модель, що застосовується в наукових дослідженнях, має відповідати таким вимогам [6]: однозначно подавати (з необхідною глибиною деталізації) відповідні об’єкти дослідження, що створені природою чи людиною; бути допоміжним, природнім або штучним об'єктом, що замінює оригінал в процесі дослідження (на певному етапі дослідження), що здійснюється для отримання відомостей про оригінал; мати ті властивості оригіналу, що є суттєвими для певного дослідження. Різні моделі, що використовуються на практиці, можуть характеризуватись множиною властивостей (ознак), що відображають специфіку їх створення й особливості застосування [4].

Уважаємо за доцільне виокремити системний підхід як такий, що допоможе найбільш якісно розглянути модель управління освітніми ресурсами вищої освіти в Україні. Системний підхід дозволяє розв'язати проблему побудови моделі складної системи з урахуванням усіх наявних чинників. У якості загальнонаукової методологічної основи дослідження ми вибираємо системний підхід, який: 1) грунтовно розроблений, широко застосовується в педагогічних дослідженнях; 2) ураховує особливості досліджуваного предмета; 3) узгоджується із загальною метою нашого дослідження. При цьому як робоче визначення категорії «підхід» ми подаємо таке: особлива форма пізнавальної і практичної діяльності, розгляд педагогічних явищ з певної позиції, стратегія дослідження процесу, базова ціннісна орієнтація, що визначає позицію педагога [13, с. 54]. Системний підхід розроблявся в методологічних роботах (В. Афанасьєв [2], І. Блауберг [3], В. Тюхтін [14], Е. Юдін [15]).

Посилаючись на запропоновану С. Капіцою, С. Курдюмовим, Г. Малинецьким [7, с. 128-173] ісрархію математичних моделей системи, можна виокремити кілька різних (вертикальних) рівнів структурної ієрархії системи вищої освіти: макросистема - система освіти в цілому, яка характеризується взаємодією і взаємовпливом системи освіти і системи суспільних відносин; мезосистема - система вишівської освіти; мікросистема - соціальна система, функціонування якої пов'язане 3 безпосередньою діяльністю 3 підготовки і професійного становлення спеціаліста в межах конкретної освітньої організації, що виражається насамперед у навчальному процесі ВНЗ. Система нижчого рівня $є$ уподобанням і символом більшого, це своєрідний «мікрокосм», у якому розкрито таємниці «макрокосму». Щодо управління на різних рівнях організації вищої освіти, суб'єкт-об'єктні взаємозв'язки в системі управління вищою освітою набувають характеру: а) субординації (за вертикальними зв'язками), яка характеризується слабким зворотним зв'язком або взагалі його відсутністю; б) координації (за чисельними горизонтальними зв'язками), що дозволяють реалізувати основні функції управління більш адекватно й ефективно. Управління не може зводитися лише до зовнішнього управління у вигляді ієрархічної моделі, воно повинно поєднуватися з самоорганізацією на кожному рівні ієрархії. Кожна компонента управління кожного рівня ієрархії формує поле можливостей для компонент нижчого рівня. Це дозволяє сформувати оптимальне управління, тоді як лінійне управління такої можливості не має. Функціонування будь-якої системи немислиме без управління. Можна говорити про наявність природного взаємозв'язку системного підходу та теорії управління. В основі такого взаємозв'язку лежить відповідність цілей існування об'єкта як системи та цілей управління ресурсами системи, що забезпечують їі цілісність. При цьому система управління розглядається як сукупність дій, необхідних для погодження спільної діяльності людей. У процесі управління інформація трактується як функція (спрямування) й комунікація (зв'язок). У процесах управління інформація відіграє не просто головну роль, а є основою, сутністю самого управління як процесу організації цілеспрямованого впливу на об'єкт для його функціонування за заданою програмою. Процес інформаційного моделювання організації об'єктів у цілісну систему повинен ураховувати динаміку їх розвитку на основі опису різноманіття інформаційних внутрішніх і зовнішніх зв'язків. Такі зв'язки створюють передумови до побудови найкращої (оптимальної) структури [1]. Системний підхід до управління системою управління освітніми ресурсами вищої освіти України означає, що компоненти системи й різноманітні зв'язки як усередині, так і поза нею досліджуються не ізольовано, а під кутом їхніх взаємозв'язків і взаємозалежностей. У будь- 
якій системі відбувається обмін між ії елементами або інформацією. Об'єднання елементів у функціональну структуру створює дещо ціле, якісно відмітне від іiі частин. Можливості виокремленої або створеної цілеспрямованої системи завжди відрізнятимуться від можливостей, що входять до системи елементів. Нові якості, властиві системі в цілому, але не властиві жодному з її елементів окремо, прийнято називати інтеграційними якостями системи. Отже, модель управління освітніми ресурсами вищої освіти в Україні - це спрощена форма уявлення реальних процесів і взаємозв'язків з середовищем у системі вищої освіти, яка дозволяє управляти наявними елементами (чинниками), які впливають на поведінку системи загалом, що є інтегрованою єдністю.

Етапи реалізації можливостей системного підходу в процесі створення системи необхідно виконати такі вимоги: визначити мету функціонування системи, функціональні зв'язки підсистем і перелік розв'язуваних ними завдань; урахувати всі (або як мінімум основні) чинники, які впливають на систему, і дослідити їх характеристики; розробити модель системи; визначити показники ефективності функціонування системи [11, с. 15]. Треба враховувати також системні властивості, а саме: наявність різноманіття функціональних взаємозв'язків (позитивних, негативних, гармонізованих) і взаємовідносин між елементами систем, що відносяться до різнорівневих, цілісних структурних утворень. Якщо системні властивості структурних утворень порушуються, то виникають кризові ситуації на всіх рівнях ієрархічної структури. Накопичення таких ситуацій у середовищі призводить до системної кризи в тому випадку, якщо відсутнє оперативне їх розв'язання. Криза в системі настає тоді, коли іiї якість уже не відповідає заданим кількісним параметрам. Гармонізацію інформаційних зв'язків у соціально-економічній системі потрібно розглядати як метод динамічного «урівноваження» позитивних і негативних результатів взаємодії безлічі зв'язків і відносин у соціальноекономічних елементах при збереженні цілісності системи управління освітніми ресурсами вищої освіти в природному середовищі. Ця гармонізація можлива за допомогою системного світогляду (сучасний науковий метод пізнання всіх явищ і процесів, що відбуваються в об'єктивному світі на основі логіки системних досліджень) і системного мислення (здатність до синтетичного сприйняття об'єктів реальної дійсності й усвідомленому розумінню різноманіття інформації, властивої цілісній картині світу).

Отже, модель управління освітніми ресурсами вищої освіти в Україні - це спрощена форма уявлення реальних процесів і взаємозв'язків із середовищем у системі вищої освіти, яка дозволяє управляти наявними елементами (чинниками), які впливають на поведінку системи загалом, що $\epsilon$ інтегрованою єдністю. Система управління освітніми ресурсами вищої освіти $\epsilon$ соціальною, штучною, відкритою, динамічною, складною і діяльною системою. Гармонізація управління освітніми ресурсами вищої освіти можлива за допомогою системного світогляду і системного мислення.

\section{Література}

1. Алексеева М. Б. Основы теории систем и системного анализа / М. Б. Алексеева, С. Н. Балан. СПб. : Санкт-Петербургский государственный инженерно-экономический университет, 2002. - 55 с. 2. Афанасьев В. Г. Системность и общество / В. Г. Афанасьев. - М. : Изд-во полит. лит-ры, 1980. 368 с. 3. Блауберг И. В. Проблема целостности и системный подход / И. В. Блауберг. - М. : Эдиториал УРСС, 1997. - 448 с. 4. Гич Дж. Прикладная общая теория систем: [пер. с англ.] / Дж. Гич. М. : Мир, 1981. - Т. 1. - 336 с. 5. Глузман Н. А. Моделювання процесу формування професійної компетентності майбутніх фахівців / Н. А. Глузман // Сучасні інформаційні технології та інноваційні методики навчання і підготовки фахівців: методологія, теорія, досвід, проблеми. - 2012. - № 31. С. 311-318. 6. Калапуша Л. Р. Моделювання у вивченні фізики / Л. Р. Калапуша. - К. : Рад. школа, 1982. - 158 с. 7. Капица С. П. Синергетика и прогнозы будущего / Капица С. П., Курдюмов С. П., Малинецкий Г. Г. - М. : Наука, 1997. - С. 128-173. 8. Лодатко Є. О. Моделювання в педагогіці: точки відліку [Електроний ресурс] / Є. О. Лодатко // Педагогічна наука: історія, теорія, практика, тенденції розвитку : Е-журнал. - 2010. - Вип. №1 - Режим доступу: - http://intellectinvest.org.ua/pedagog_editions_e- magazine_pedagogical_science_vypuski_n1_2010_st_2. 9. Михеев В.И.

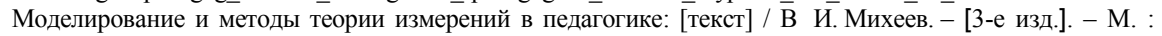
КомКнига, 2006. - 200 с. 10. Раяцкас Р. Л. Система моделей планирования и прогнозирования / Р. Л. Раяцкас. - М. : Экономика, 1976. - 296 с. 11. Самарский А. А. Математическое моделирование. Идеи, методы, примеры / А. А. Самарский, А. П. Михайлов. - [2-е изд., испр.]. - М. : Физматиздат, 2001. - 316 с. 12. Сергеева В. П., Грицаева С.В. Основы управления педагогическими системами : 
[программно-метод. пособ.] / В. П. Сергеева, С. В. Грицаева. - М., 1999. - 93 с. 13. Системное познание мира: методологические проблемы / А. Н. Аверьянов. - М. : Политиздат, 1985. - 263 с. 14. Словарь-справочник педагогических инноваций в образовательном процессе / [сост. Л. В. Трубайчук] . - М. : Восток, 2001. - 81 с. 15. Тюхтин В. С. Диалектика познания сложных систем / В. С. Тюхтин [и др.]; под ред. В. С. Тюхтина. - М. : Мысль, 1988.- 316 с. 16. Юдин Э. Г. Системный подход и принцип деятельности: методологические проблемы современной науки / Э. Г. Юдин. - М. : Наука, 1978. - 391 с.

Наталія Чувасова

\section{КРЕАТИВНІСТЬ ОСОБИСТОСТІ: ЗМІСТ І СТРУКТУРА}

Чувасова Н. О. Креативність особистості: зміст і структура.

У статті розглядаються різні підходи до визначення змісту і структури креативності та творчості особистості. На основі здійсненого аналізу автор виокремлює критерії та показники формування креативності майбутніх педагогів природничих дисциплін в умовах університету.

Ключові слова: креативність, креативне мислення, креативне навчання, творчість, обдарованість, творчі здібності, творча особистість.

Чувасова Н. А. Креативность личности: содержание и структура.

В статье рассматриваються различные подходы к определению содержания и структуры креативности и творчества личности. На основе проведенного анализа автор выделяет критерии и показатели формирования креативности будущих педагогов естественных дисциплин в условиях университета.

Ключевые слова: креативность, креативное мышление, креативное обучение, творчество, одаренность, творческие способности, творческая личность.

Chuvasova N. A. Personality creativity: the content and structure.

Some different approaches to the determination of the content and the structure of the Natural Sciences teacher-to-be's creativity have been considered in the article. Taking as a base the analysis carried out, the author has determined the criteria and the indicators of the Natural Sciences teacherto-be's creativity while studying at University.

Keywords: creativity, creative thinking, creative teaching, creation, endowment, creative abilities, creative person.

Нині в Україні, як і в усьому світі, створюються передумови для перегляду теоретичних основ і технологій підготовки майбутніх педагогів природничих дисциплін до професійної діяльності. Подолання репродуктивного стилю підготовки майбутніх фахівців і перехід до нової освітньої парадигми передбачає і нові вимоги до підготовки майбутніх педагогів природничих дисциплін, які забезпечують пізнавальну активність, креативність дій i самостійність мислення особистості і $€$ стратегічними напрямами в модернізації вищої педагогічної освіти. На сучасному етапі перед вищими навчальними закладами постає завдання переорієнтувати навчальний процес на формування креативної особистості, здатної самостійно здобувати знання з різних джерел інформації та застосовувати їх у практичному житті.

Проблема креативності досліджувалася багатьма зарубіжними та вітчизняними науковцями, зокрема, такими, як: Д. Богоявленська, Н. Вишнякова, Дж. Гілфорд, В. Клименко, А. Лук, С. Мєднік, Л. Міщиха, В. Моляко, М. Ніколаєнко, Я. Пономарьов, В. Роменець, С. Рубінштейн, К. Тейлор, Е.Торренс, М.Уоллах, Д. Халперн, М. Ярошевський та ін.

3-поміж праць із психології творчості можна знайти розроблення різноманітних їі аспектів. Це, зокрема, спроби пояснити сутність творчості та творчого процесу (В. Моляко, М. Ніколаєнко, Я. Пономарьов, В. Роменець та ін.), визначити специфіку творчості в тій чи тій галузі знань (Т. Кудрявцев, М. Ярошевський та ін.), пошук шляхів оптимізації та активізації творчого мислення (Г. Альтшуллер, Г. Буш, В. Моляко, І. Семенов та ін).

Важливу роль у розробленні основ теорії творчої особистості відіграли дослідження закономірностей творчого процесу в різноманітних видах діяльності, які знайшли своє 